\title{
The Pragmatics Model of Bhur'maen "Beggar" Madura in Social Construction Perspective
}

\author{
Fajar Surahman $^{1}$, Ishomuddin ${ }^{2}$, Tri Sulistyaningsih ${ }^{2}$, Rinikso Kartono ${ }^{2}$ \\ ${ }^{1}$ Universitas Madura, Indonesia \\ ${ }^{2}$ Universitas Muhammadiyah Malang, Indonesia \\ suryasurayafajar@gmail.com
}

\begin{abstract}
Bhur'maen is a social entity in Madurese terminology that is pinned on certain people or forms of society that are accustomed to begging for daily activities in the form of harvests or money whose modus operandi is to visit people's homes. This study aims to understand by describing the phenomenon of social problems in the context of the habits of the bhur'maens in Madura which have been carried on for generations (regeneration), thereby popping the pragmatic model of the bhur'maen community in the perspective of social construction. The analytical approach used is a qualitative approach. In the interest of this research the research paradigm rests on the paradigm of social definition by using the dialectical model of Peter L. Berger and Thomas Luckmann's Social Construction as a theoretical foundation for a sociological perspective, which focuses on the social construction of society towards the reality of bhurmaens in the Tlanakan area of Pamekasan Madura which is stigmatized as a sub-district of bhurmaen. Data collection is done by observation, interview, documentation and focus group discussion (FGD) techniques. The results and in-depth discussion in the research show: First, that the socio-cultural construction of bhur'maen is formed based on the knowledge and experiences of individuals and or actors in understanding the reality of bhur'maens in Madura. Secondly, that the bhur'maen socio-cultural construction is formed based on the values that are held by individuals and or actors in understanding the reality of bhur'maens in Madura. Third, that the socio-cultural construction of bhur'maen is formed based on the recognition (legitimacy), beliefs and beliefs of individuals and / or actors in understanding the reality of bhur'maen in Madura.
\end{abstract}

Keywords

Bhur'maen society, social construction, poverty

\section{Introduction}

Indonesia as a developing country is now constantly trying to implement efforts for social change and development and to overcome various social problems that occur. One of the social problems faced by the Indonesian people that has never been resolved is the problem of poverty, to overcome it requires attention, commitment and joint action both the government, the academic community, scholars, experts, professionals, nongovernmental organizations (NGOs), and other community groups (Syawie, 2011, Sutisna, 2013).

The problem of poverty requires handling priority scale, in a serious and comprehensive way because the problem of poverty has an impact on other social problems (Syawie, 2011, Pratama, 2014). Poverty often has bad implications that can lead to unemployment, ignorance, illiteracy, low work ethic, depressed self-esteem and even unproductive household conditions so that the potential for homeless people and even 
beggars to be created as a shortcut to their survival (Sumarti, 2007, Putera, 2011, Berger et al., 2013).

In the view of Islam, poverty is close to kufr (Abdurrahman, 2003). It is not uncommon to find people willing to sacrifice their self-esteem to frequently visit crossroads, overhanging shops, offices, religious tourism places and even visiting the houses of local residents only to carry out activities as beggars (Humaidy, 2003, Fikri et al., 2016, Syakur and Panuju, 2020). In this context what is meant by beggars are people who earn income by begging in public in various ways and reasons to expect mercy from others (Permensos, 2012).

Preliminary studies conducted by researchers as a first step in the interests of this research, found interesting phenomena that occur in the "bhur'maen community" Tlanakan Pamekasan Madura. Tlanakan is an area that until now bears the nickname of "the sub-district of the bhur'maen" because there are a number of areas in the sub-district where residents in their search for income from their livelihoods as a bhur'maen.

Based on the results of the observation revealed the fact that bhur'maen's activity is not merely an economic problem but has shifted to the realization of a kind of culture. Because of the strengthening of the mindset of "bhur'maen society" which has been strongly rooted in hereditary bhur'maen mentality, even though the government had empowered an empowerment program in an effort to overcome the "bhur'maen community" behavior in the form of capital assistance business and maintenance of livestock, but did not also achieve an effective goal because a few months after surrender, it turns out that the livestock were not kept for breeding but sold, while the handing over of business capital as sistance was not used according to its designation. They consider their income to be more comfortable than pet's (Syakur et al., 2020).

Bhur'maen, which in our republic is commensurate with the term beggar, is a social entity in Madurese terminology that is pinned on people or certain forms of society that are accustomed to begging in daily life in the form of harvests or money whose modus operandi goes to homes resident. The existence of bhur'ma in the level of theoretical phonology cannot be separated from the cultural conception of poverty (cultural poverty). As stated by (Lewis, 1959), states that poverty can arise as a result of the values and / or culture adopted by the poor, such as lazy, easy to give up on fate, lack of work ethic. External factors come from outside the ability of the person concerned, such as bureaucracy or official regulations that can hamper someone in utilizing resources (Pratama, 2014). This kind of poverty is often called structural poverty, which assumes that poverty occurs not because of the unwillingness of the poor to work, but because of the inability of social systems and structures to provide opportunities for them to work and obtain sources of income in order to create a prosperous life (Soekanto, 1999, Humaidy, 2003).

The existence of beggars as a series of social problems is a reality that was born as a domino effect in a culture of poverty (Nurwati, 2008, Nurkaidah, 2016). The conception stated by (Humaidy, 2003) that poverty is dichotomized in 2 (two) substantial types, namely: First, material beggars are poor, in this case beggars whose economic conditions are indeed difficult or unable, so they decide to look for income through beg. This condition, the existence of the developer is very closely related to the poverty of a society in the economic field (Fikri et al., 2016). This kind of poverty according to the Central Statistics Agency (BPS) is a poverty related to the inability of a person from the economic side to meet the basic needs of food and not food measured from the expenditure side (Statistik, 2018). Thus, it can be articulated that the poor population is a population that has an average per capita expenditure per month below the poverty line. Secondly, mentally poor beggars, in this case 
are beggars whose economic conditions are still relatively capable, but they still beg because they have mental lazy to try to find income through better jobs (Humaidy, 2003)

Entity "bhur'maen community in Madura would be easily traced to its existence in 2 (two) districts, namely Sumenep and Pamekasan who were stigmatized as the basis of" bhur'maen society ". Pamekasan Madura, which of course has invited its own attraction because it is part of social problems (social problems) in the community of developing countries like Indonesia. In the methodological perspective of social science that the phenomenon is a matter of the gap between expectations (dos sallen) and reality (das sein).

The reality of the bhur'maen that occurs in the Tlanakan Pamekasan Madura community on their journey takes a different view from each individual. Different views about the existence of bhur'maen itself are actually born from the construction process of individuals in their social context (Jonnadi et al., 2012). Social construction according to (Berger et al., 2013), is a contemporary sociology theory that rests on the sociology of knowledge. This theory emphasizes more on human actions as creative actors than their social reality. Social reality is a social construction created by individuals. Individuals are free human beings who have relations between one human and another human (Soekanto, 1999). The individual becomes a determinant in the social world that society has constructed based on his will. This theory contains an understanding that reality is socially constructed, and reality and knowledge are two key terms for understanding it (Syawie, 2011). Reality is a quality that is contained in phenomena that are recognized as being, and are not dependent on human will, whereas knowledge is certainty that phenomena are real and have specific characteristics. In other words, social construction encompasses everything that becomes the individual's knowledge of his social reality (Syawie, 2011, Syakur, 2018).

The theory of social construction offered by (Berger et al., 2013) there are 3 (three) simultaneous dialectical moments about social construction (reality construction) consisting of externalization, objectification, and internalization. First, Externalization is anything that is outside the individual self. This externalizing moment is objective for individuals in their social reality. This externalizing moment manifests itself in the social structure of a society, rules, religious texts, customs and or habits of the community. This externalizing moment is functional and influences individuals in their actions, behavior, and interaction patterns (Berger et al., 2013, Katmini and Syakur, 2020). Second, objectification is a process of institutionalizing external values. This moment is basically as a process, where external values, such as social structure, religious texts, rules, customs and or habits in social reality that are objective, delivered, distributed, and / or distributed to individuals, which subsequently by individuals who receive it serve as a handle values to carry out a construction process. Third, Internalization is a process of re-absorption of individuals against values that are external and conveyed to themselves through a process of objectification, which then gives birth an individual's knowledge and actions towards the reality they construct.

\section{Research Methods}

This research is included in field research with a qualitative approach (Imam, 2013). Research with a qualitative approach is a research process that is not intended to carry out statistical tests including the problems formulated, but only provides an in-depth description or description of the problem according to data and information from the field through subject or respondent, and even research informants according to interpretation or interpretations from researchers (Harrison, 2016). 
While the type of research used by the case study method as described by (Imam, 2013). Gunawan (2013), explained that the type of research with the case study method is a type of research that is specific and specific. Specificity and specificity in this study, lies in the systematic efforts undertaken by researchers in the research process, so that the format of the "Pragmatic Model of Bhur'maen Perspective of Social Construction" is a case study in the Tlanakan Pamekasan Madura community.

Data collection techniques used in the interests of this study used observation, interviews (interview), documentation, and Focus Group Discussion (FGD). While the analysis of data analysis techniques used in the interests of this study uses theory (Miles and Huberman, 1994), namely analyzing data with 3 (three) steps, namely: condensation of data (condensation), presenting data (display) and drawing conclusions or verification (conclution drawing and verivication). Data condensation refers to the process of selecting, extracting, simplifying, summarizing, and transforming data.

In order to test the validity of the data, in this study using triangulation techniques (Walidin and Idris, 2015). Triangulation is a data validity checking technique that utilizes something else. While the triangulation technique used, is the source triangulation technique. Triangulation technique with sources according to Moleong means comparing and checking back the degree of trust in information obtained through different time and tools, this technique is often used in qualitative research. The technique of triangulation of data sources as referred to in this study through several mechanisms is comparing data from observations with data from interviews, comparing the results of interviews with the contents of a related document.

\section{Discussion}

The history of the emergence of "bhur'maen society" in Madura may be traced to its existence in two districts, namely Sumenep and Pamekasan, it is evident that in this region it will be easily found which is known by the public (public) based on the "bhur'maen community" or the mention of others are known as "bhur'maen" villages. The existence of "bhur'maen" villages is closely related to folklore that develops in the midst of local communities. As one person said in his capacity as a community leader at the study site, it was said that in the past in his village there was one of the relocated religious leaders from Sumenep district named Ki Moko. One time, Ki Moko, who was a guest from the Kingdom, wanted to buy the abundant agricultural produce in his village to be presented to the king. But residents refused to sell their crops and fruits to Ki Moko. Finally, with a very disappointed feeling, Ki Moko with his supernatural powers condemned the local residents, that is "someday the people who live in this area will experience hardships".

The phenomenon of bhur'ma which occurs in Madura has a contradictory relationship with social values that are interspersed with religious values. These values are a form of regional uniqueness that is highly valued by the majority of Madurese people. As for the social values as intended namely: First: A very strong philosophy in the life of Madurese people related to work ethic, "abental ombe", asapo 'wind, floating faith "(padded in waves, covered in wind, covered in faith) which implies the meaning that the tenacity of someone in work that never gives up because for him work part of the faith. Second: philosophy related to prestige and self-existence, "etembheng pote matah ango'an pote tolang" (rather than white eyes better bone white) which contains meaningful expressions about the principle of betting to maintain self-esteem so as not to fall from behavior that causes humiliation in social life including also in defense of his close relatives and the religion they profess. Third: Philosophy related to discipline and consistency in social ethics, "ngico" tengka lanjheng 
tobet "(injuring behavior will long repent) which implies the attitude of one's vigilance in acting which involves social ethics, because once injured by its actions the solution is very complicated. Fourth: The religious value which implies that "the hand above is better than the hand below", which implies that giving is better than asking. Understanding the strength of the philosophy and spirit of life which is based on regional distinctiveness values that are highly valued by the majority of Madurese people, it becomes a dilemma when contextualized by the existence of "bhurmaen society" behavior in the Tlanakan area of Pamekasan Madura.

Moment of externalization, objectification and internalization will always always proceed dialectically in society (Berger et al., 2013). Through continuous human action and interaction, institutions in society will be created and maintained or changed. Although society and social institutions look objectively real, but in reality everything is built in a subjective definition through a process of interaction. Therefore, new objectivity can occur through repeated affirmations given by others who have the same subjective definition. In the highest level of generality, humans create the world in a symbolic meaning that is universal, namely a holistic view of life, which gives legitimacy and regulates social forms and gives meaning to various fields of life.

The results of research on bhurmaen culture in Madura in this case consist of several important findings, namely: First: The construction of the subject of bhur'maen culture as an objective and subjective reality in the Tlanakan community of Pamekasan Madura. Second: Subject construction of social values about bhur'maen culture in the Tlanakan Pamekasan Madura community. Third: Subjeck construction of the absorption of social values into the reality of bhur'maen in Tlanakan Pamekasan Madura.

\subsection{The Subjeck Construction of Bhur'maen Culture as an Objective and Subjective Reality}

Each individual has the freedom to interpret his reality in accordance with the values they carry, and or according to his own desires (Berger et al., 2013). In this context socializes that the subjectivity of one's knowledge and experience, which is different from others, has an urgency in constructing a particular social reality. Therefore, the interpretation of the subjective social world itself will open up opportunities for multiple realities. As social beings in their lives, humans are always faced with various social problems (social problems). Indeed social problems are an inseparable part of human life itself because social problems are manifested as a result of human culture itself, as a result of its relationships with others and as a result of its behavior.

Table 1. Subjective in this study has several meanings construction

\begin{tabular}{|c|c|c|}
\hline No & $\begin{array}{c}\text { Construction } \\
\text { Meanings }\end{array}$ & Description of Research Findings \\
\hline 1. & Social Stigma & $\begin{array}{l}\text { The subject of research knowledge from the findings } \\
\text { of researchers in the field about bhur'maen culture in } \\
\text { the Tlanakan Pamekasan Madura community in this } \\
\text { case is constructed as a form of labeling and / or } \\
\text { stigma attached to the habits of people in the Tlanakan } \\
\text { region. This fact shows that the region is always } \\
\text { identified with the basis of the bhur'maen by the } \\
\text { general public (public), even to the point of } \\
\text { mentioning it as a village "bhur'maen". As happens } \\
\text { when there is a discussion about the phenomenon of }\end{array}$ \\
\hline
\end{tabular}




\begin{tabular}{|c|c|c|}
\hline No & $\begin{array}{l}\text { Construction } \\
\text { Meanings }\end{array}$ & Description of Research Findings \\
\hline & & $\begin{array}{l}\text { bhur'maen because it is often unsettling for his } \\
\text { behavior, the understanding of the general public is } \\
\text { often aimed at this region. Construction in the form of } \\
\text { knowledge is formed based on personal experiences } \\
\text { and personal nature of each subject and or research } \\
\text { informants in their social reality. }\end{array}$ \\
\hline 2. & $\begin{array}{l}\text { Opportunities and } \\
\text { Opportunities }\end{array}$ & $\begin{array}{l}\text { The informant's knowledge from the findings of } \\
\text { researchers in the field about the culture of bhur'maen } \\
\text { in the Tlanakan Pamekasan Madura community, there } \\
\text { was a construction of meaning that the behavior of } \\
\text { bhur'maen behavior in the Tlanakan community was } \\
\text { caused by the factors of opportunity and opportunity. } \\
\text { This fact can be seen with the tourist area "natural fire } \\
\text { that never goes out" which happens to be in the region, } \\
\text { where almost every day busy visiting tourists. This } \\
\text { momentum is often used by people around to carry out } \\
\text { the action to beg for money to tourists in the tourist } \\
\text { area with the aim of earning an economical income. }\end{array}$ \\
\hline 3. & Social Imitation & $\begin{array}{l}\text { Informant knowledge from the findings of researchers } \\
\text { in the field about the culture of bhur'maen in the } \\
\text { Tlanakan Pamekasan Madura community, there is a } \\
\text { construction of meaning that, bhur'maen culture in the } \\
\text { social reality of the Tlanakan community occurs } \\
\text { because of the imitation process. This process is a } \\
\text { process of imitating the patterns of behavior, actions, } \\
\text { and behavior carried out by people in general. Thus, } \\
\text { this imitation process is a process that is very possible } \\
\text { to give birth to a new generation in perpetuating the } \\
\text { bhur'maen culture in society. }\end{array}$ \\
\hline 4. & Work ethic & $\begin{array}{l}\text { Informant knowledge from the findings of researchers } \\
\text { in the field about the culture of bhur'maen in the } \\
\text { Tlanakan Pamekasan Madura community, there is a } \\
\text { construction of meaning that, reality about the } \\
\text { behavior of bhur'maen behavior in the Tlanakan } \\
\text { community is very closely related to the work ethic of } \\
\text { the perpetrators of those who carry out activities as } \\
\text { bhur'maenitu alone. This work ethic is also a form of } \\
\text { motivation that a person has to work in his social } \\
\text { context. The work ethic and / or work motivation of } \\
\text { the bhur'maens in the Tlanakan community is } \\
\text { constructed in the form of laziness and lack of desire } \\
\text { to work hard, so that in this context, those who carry } \\
\text { out activities as bhur'maens have no shame. }\end{array}$ \\
\hline 5. & $\begin{array}{l}\text { Character and } \\
\text { Character }\end{array}$ & $\begin{array}{l}\text { Informant knowledge from the findings of researchers } \\
\text { in the field about the culture of bhur'maen in the } \\
\text { Tlanakan Pamekasan Madura community, there is a } \\
\text { construction of meaning that the behavior of }\end{array}$ \\
\hline
\end{tabular}




\begin{tabular}{|l|l|l|}
\hline No & \multicolumn{1}{|c|}{$\begin{array}{c}\text { Construction } \\
\text { Meanings }\end{array}$} & \multicolumn{1}{c|}{ Description of Research Findings } \\
\hline & $\begin{array}{l}\text { bhur'maen behavior occurs in the Tlanakan community } \\
\text { due to character and character. This fact shows that } \\
\text { those who carry out activities as bhur'maen are related } \\
\text { to personality mentality, this is also closely related to } \\
\text { the loss of shame as in dictum } 4 \text { (four) above. People } \\
\text { who do bhur'maen activities are not because of the } \\
\text { unavailability of jobs in other sectors, but because it } \\
\text { has become their character and character who do not } \\
\text { want to bother and work hard so that they perpetuate } \\
\text { the bhur'maen culture itself. }\end{array}$ \\
\hline
\end{tabular}

Source: Reworked research results, 2020.

\subsection{Subject Construction of Social Values about Bhur'maen Culture}

Values as shared options (shered preferences). Values are basic principles and beliefs that act as general guidelines for acting, in which case values are interpreted as ideas that are hereditary considered true and important by members of community groups (Nurwati, 2008, Syuhada, 2019). Value is a product of social interaction, and hereinafter referred to as social value, which is an abstract concept in humans about something that is considered good and right, also something that is considered wrong, and bad. The existing value system in a society is used as an orientation and reference in acting.

The spectrum above shows that each individual in carrying out social activities is always based on and / or guided by existing values or value systems and lives in the community itself. This can be articulated that the values themselves greatly influence human actions and behavior, both individually and in groups. Fundamentally humans are not entirely determined by the environment, which in this case can be articulated that the process of socialization is not a complete success, humans have the opportunity to externalize or collectively shape their social world, and in turn externalization results in social change (Pratama, 2014, Syakur, 2014).

Table 2. The construction of meaning of the findings of this study

\begin{tabular}{|c|l|l|}
\hline No & \multicolumn{1}{|c|}{$\begin{array}{c}\text { Construction } \\
\text { Meanings }\end{array}$} & \multicolumn{1}{c|}{ Description of Research Findings } \\
\hline 1. & $\begin{array}{l}\text { Regional } \\
\text { characteristics and } \\
\text { waning fading }\end{array}$ & $\begin{array}{l}\text { Social reality about the phenomenon of bhur'maen is } \\
\text { constructed as an attitude related to the shifting of } \\
\text { social values. These social values concern the cultural } \\
\text { values of Madura's local wisdom which is a guide in } \\
\text { its social process. The cultural values of local wisdom } \\
\text { in the Madurese community are related to the } \\
\text { characteristics of individuals who have a hard working } \\
\text { spirit. In the social order of the Tlanakan people, it } \\
\text { turns out that shows the social reality which is } \\
\text { inversely proportional to the custom of bhur'maen. }\end{array}$ \\
\hline 2. & $\begin{array}{l}\text { Lack of economic } \\
\text { independence }\end{array}$ & $\begin{array}{l}\text { The social reality of the phhenema bhur'maen is } \\
\text { constructed as an attitude related to the absence of its } \\
\text { main independence in economic aspects. This lack of } \\
\text { independence is indicated by the attitude of being lazy, } \\
\text { not willing to work hard and so on so that it has the }\end{array}$ \\
\hline
\end{tabular}




\begin{tabular}{|c|l|l|}
\hline No & \multicolumn{1}{|c|}{$\begin{array}{c}\text { Construction } \\
\text { Meanings }\end{array}$} & \multicolumn{1}{c|}{ Description of Research Findings } \\
\hline 3. & Poor mentality & $\begin{array}{l}\text { potential to form new structures. As happened in the } \\
\text { Tlanakan community, that economic self-sufficiency } \\
\text { has given birth to individuals who carry out and } \\
\text { perpetuate customary acts of bhur'maen. }\end{array}$ \\
\hline $\begin{array}{l}\text { Social reality about the phenomena of bhur'maen is } \\
\text { constructed as a trait related to the poor mentality of } \\
\text { those who practice bhur'maen. This mentality is not } \\
\text { because they do not have the ability to get work in } \\
\text { other sectors in order to earn an income in their lives, } \\
\text { but rather due to laziness. This condition is } \\
\text { deliberately maintained by those who practice } \\
\text { bhur'maen for personal gain and comfort. This } \\
\text { mentality is very closely related to morality which is } \\
\text { based on religious and cultural values, and self-esteem. } \\
\text { As happened in the Tlanakan community, that people } \\
\text { do the habit of bhur'maen it turns out that there is no } \\
\text { shame and always feel lacking but there is no } \\
\text { willingness to work hard. }\end{array}$ \\
\hline
\end{tabular}

Source: Reworked research results, 2020.

\subsection{Subjeck Construction of the Absorption of Social Values into the Reality of Bhur'maen}

Social construction (social construction) in the mouth gave birth to new actions and identities of individuals who carry out the construction process in the context of the social. Social construction describes the process in which through actions and interactions, individuals create continuously a reality that is shared which is experienced factually objective and meaningful subjectively (Wijayanto and Arianti, 2010). The instrument in creating objective social reality through an externalization process, as it influences it through an internalization process that reflects subjective reality (Berger et al., 2013).

There was a shift in pressure toward beliefs, motivations, and goals in community members, all of which gave content and form to their behavior (Wirawan, 2013). The word behavior is used for actions which for the actor and / or actor have a subjective meaning (Soekanto, 1999). The perpetrator wants to achieve a goal or he is motivated by motivation. Behavior becomes social occurs only if and to what extent the subjective meaning of the behavior makes the individual think and show a uniformity that is more or less fixed (Nurwati, 2008). The concept of the verstehen approach to understanding the meaning of one's actions assumes that a person in acting does not merely implement it but also places himself in the environment of other people's thinking and behavior (Soekanto, 1999, Syawie, 2011).

Based on in-depth discussions between research findings with a theoretical basis and interpretation of research findings on the process of re-absorption of values as a result of construction that gives birth to the rationality, actions and identity of new individuals in the reality of bhur'maen culture in the Pamekasan Madura Tlanakan Society, as in the following table: 
Table 3.

\begin{tabular}{|c|c|c|}
\hline No & $\begin{array}{l}\text { Construction } \\
\text { Meanings } \\
\end{array}$ & Description of Research Findings \\
\hline 1. & Unethical work & $\begin{array}{l}\text { The bhur'maen culture is constructed as an unethical } \\
\text { occupation and / or profession. This kind of } \\
\text { knowledge is formed through the process of absorbing } \\
\text { the values carried out by individuals towards the } \\
\text { behavior and actions of the bhur'mas in the Tlanakan } \\
\text { Society. Social construction (social construction) about } \\
\text { the reality bhur'maen, can not be separated from the } \\
\text { biographical profile, social background, and the handle } \\
\text { of individual values in this case is the subject of } \\
\text { research in providing meaning construction about the } \\
\text { reality of bhur'maen in the Tlanakan Society } \\
\text { Pamekasan Madura. }\end{array}$ \\
\hline 2. & Inappropriate action & $\begin{array}{l}\text { The bhur'maen culture is constructed as an act of } \\
\text { unreasonableness. Individual knowledge about the } \\
\text { reality of bhur'maen in the Tlanakan Society has a } \\
\text { construction of meaning that those who practice as } \\
\text { bhur'maen belong to the category who want to live } \\
\text { well but are lazy to work. Social construction (social } \\
\text { construction) about the reality of bhur'maen, can not } \\
\text { be separated from the biographical profile, social } \\
\text { background, and the handle of individual values which } \\
\text { in this case is the subject of research in providing } \\
\text { meaning construction about the reality of bhur'maen in } \\
\text { the Tlanakan Pamekasan Madura community. }\end{array}$ \\
\hline 3. & Blinding heart & $\begin{array}{l}\text { The bhur'maen culture is constructed as an action } \\
\text { related to a person's low self-esteem. Those who } \\
\text { practice as bhur'maen are those who are categorized as } \\
\text { people who have no shame and pride. Social } \\
\text { construction (social construction) about the reality } \\
\text { bhur'maen, can not be separated from the biographical } \\
\text { profile, social background, and the handle of } \\
\text { individual values in this case is the subject of research } \\
\text { in providing meaning construction about the reality of } \\
\text { bhur'maen in the Tlanakan Society Pamekasan Madura }\end{array}$ \\
\hline 4. & $\begin{array}{l}\text { Earnings that do not } \\
\text { sweat }\end{array}$ & $\begin{array}{l}\text { The bhur'maen culture is constructed as an action that } \\
\text { is not included in the category of work. This can be } \\
\text { articulated that, the action bhur'maen an act of } \\
\text { someone who earns income materially and financially } \\
\text { without producing services or goods. Social } \\
\text { construction (social construction) about the reality of } \\
\text { bhur'maen, can not be separated from the biographical } \\
\text { profile, social background, and the handle of } \\
\text { individual values which in this case is the subject of } \\
\text { research in providing meaning construction about the } \\
\text { reality of bhur'maen in the Tlanakan Pamekasan }\end{array}$ \\
\hline
\end{tabular}




\begin{tabular}{|c|c|c|}
\hline No & $\begin{array}{l}\text { Construction } \\
\text { Meanings }\end{array}$ & Description of Research Findings \\
\hline & & Madura community \\
\hline 5. & Orang malas & $\begin{array}{l}\text { The bhur'maen culture is constructed as an action that } \\
\text { relates to one's laziness in working. The meaning } \\
\text { construction in this case can be explained that those } \\
\text { who practice 'bhur'maen' are people who physically } \\
\text { look healthy, fresh and fit, but they are lazy to earn a } \\
\text { reasonable living, but choose as bhur'maen. Social } \\
\text { construction (social construction) about the reality } \\
\text { bhur'maen, can not be separated from the biographical } \\
\text { profile, social background, and the handle of } \\
\text { individual values in this case is the subject of research } \\
\text { in providing meaning construction about the reality of } \\
\text { bhur'maen in the Tlanakan Society Pamekasan Madura }\end{array}$ \\
\hline 6. & $\begin{array}{l}\text { Damaging the image } \\
\text { of the area }\end{array}$ & $\begin{array}{l}\text { The culture of bhur'maen is constructed as an act of } \\
\text { someone which causes damage to the regional image } \\
\text { of the behavior of bhur'maen that has disturbed the } \\
\text { general public (public). This can be explained that, the } \\
\text { damage to the image of the area as a form of } \\
\text { consequence will be seen as the kampong of the } \\
\text { bhur'maens, which of course has a negative } \\
\text { connotation in their social context. Social construction } \\
\text { (social construction) about the reality bhur'maen, can } \\
\text { not be separated from the biographical profile, social } \\
\text { background, and the handle of individual values in this } \\
\text { case is the subject of research in providing meaning } \\
\text { construction about the reality of bhur'maen in the } \\
\text { Tlanakan Society Pamekasan Madura. }\end{array}$ \\
\hline
\end{tabular}

Source: Research results reinterpreted, 2020.

\subsection{The Pragmatic Model of Bhur'maen Madura}

By understanding the scientific descriptions above, the theoretical implications of the cultural phenomenon of bhur'maen in Madura in the perspective of social construction in this study, in line with the theory of social construction (social costruction) offered by (Berger et al., 2013). As the results of field studies and researchers' interpretations of research findings that have been carried out that: the results of research on social construction of the culture of bhur'maen in the Tlanakan Pamekasan Madura community, the theoretical basis is grounded in opinions (Berger et al., 2013), about the dialectical moment social construction which consists of 3 (three) aspects which are simultaneously.

Research findings and in-depth discussions as described above, in scientific readings on the theoretical implications at least give rise to conception formulations which certainly are the findings of the theory models that are reflected, namely as a form of derivation and influence of previous major theories. The definition of the definition is that:

"Pragmatic bhur'maen Madura is a social process in the form of actions, behavior, and behavior of a person with a motive for impoverishing himself and identifying as a poor person, with distinctive characteristics in carrying out the habit of begging for material and financial benefits". 
The above conception, which the researcher further defines as the "Pragmatic Model of the Madurese Madura Perspective of Social Construction" is based on individual knowledge in constructing bhur'maen actions in the Tlanakan Pamekasan Madura community, through 4 (four) important aspects namely social conditions, adaptation, goals, and patterns of interaction with dimensions of objectivity and subjectivity, in an interrelation process that ultimately gives birth to actions and behaviors, as illustrated in the following chart form:

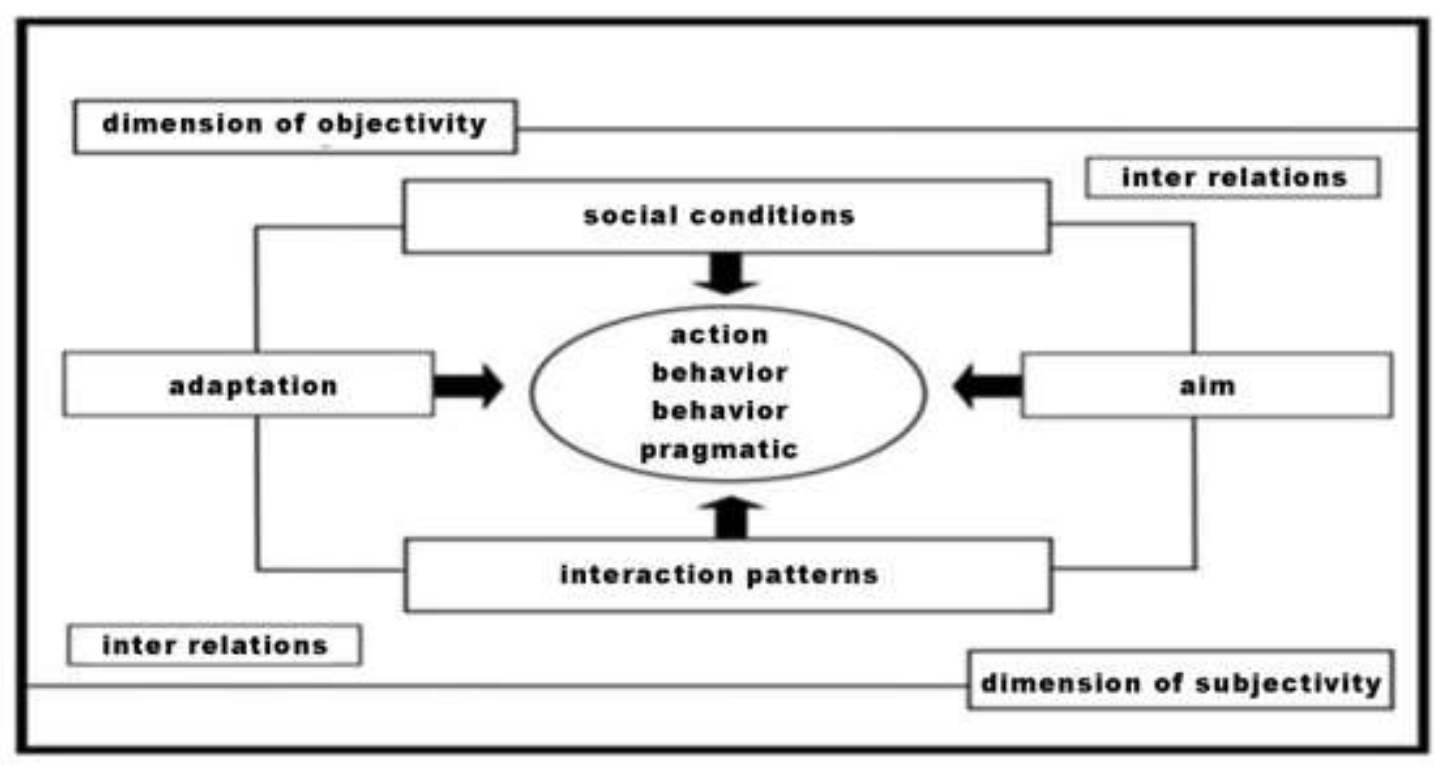

Figure 1. Bhur'maen's Madurese Pragmatic Model Perspective of Social Construction

Taking into account the form of the chart above, then in order to better understand it, it can be explained that the reality of bhur'maen in the Tlanakan Pamekasan Madura community is constructed as a pragmatic action, behavior, and behavior, which in turn these findings form the basis for the birth of renewable scientific knowledge. stipulate as "the pragmatic model of the Jurassic Madurese perspective of social construction" as a theoretical implication of the reality of the Jurur that becomes the focus and locus of researchers in conducting the research process.

Madura pragmatisbhur'maen model of social construction perspective is formed through a process of interrelation that has objective and subjective dimensions through 4 (four) important components namely social conditions, adaptation, goals, and patterns of interaction. Determination of the model is essentially influenced by several other major theories, namely: Talcott Parsons' Structural Structural Theory, George Herbert Mead's Symbolic Interactionism Theory, Erving Goffman's Sympathetic Theory.

\section{Conclusion}

Interpretation of field research findings related to the cultural phenomenon of Bhur'maen in Madura in the perspective of social construction, as a form of case study in the Tlanakan community in Pamekasan Madura, then it can be drawn a red thread to 3 (three) important points in its social reality: First, that the socio-cultural construction of Bhur'maen formed based on the knowledge and experiences of individuals and / or actors in understanding the reality of bhurmaens in Madura. Second, that the socio-cultural construction of bhur'maens is formed based on values that are held by individuals and or actors in understanding the reality of bhur'mas in Madura. Third, that the bhurmaen socio- 
cultural construction is formed based on the recognition (legitimacy), beliefs, and beliefs of individuals and or actors in understanding the reality of bhur'maens in Madura.

Theoretical implications of the cultural phenomenon of Madurese Madura in the perspective of social construction in this study, in line with the theory of social construction (social costruction) offered by Berger and Luckmann (2013). Research findings and in-depth discussions as outlined above, in scientific readings on the theoretical implications at least give rise to renewable knowledge, which is further referred to by researchers as the "Pragmatic Model of Bhur'maen Madura's Social Construction Perspective". In the context of the findings of this renewable scientific knowledge it is certainly the findings of a model theory that is reflected, namely as a form of derivation and influence of the previous major theories.

\section{References}

Abdurrahman, M. 2003. Islam sebagai kritik sosial. Erlangga.

Berger, P. L., F. M. Parera, and T. Luckman. 2013. Tafsir sosial atas kenyataan: Risalah tentang sosiologi pengetahuan. LP3ES.

Fikri, A. A. H. S., M. Sholeh, and K. Baroroh. 2016. Fenomena Kemiskinan Perkotaan (Urban Poverty) Di Yogyakarta: Suatu Kajian Struktur Dan Respons Kebijakan. Fakultas Ekonomi Universitas Negeri Yogyakarta, tt Diakses pada 16.

Harrison, L. 2016. Metodologi penelitian politik. Prenada Media.

Humaidy, M. A. A. 2003. Sosialisasi nilai pada komunitas pengemis: Studi kasus di desa Pragaan daya, Sumenep, Madura. Universitas Indonesia. Fakultas Ilmu Sosial dan Politik.

Imam, G. 2013. Metode Penelitian Kualitatif Teori dan Praktik. Jakarta: Bumi Aksara.

Jonnadi, A., S. Amar, and H. Aimon. 2012. Analisis pertumbuhan ekonomi dan kemiskinan di indonesia. Jurnal Kajian Ekonomi 1(1).

Juliantono, F. J. and A. Munandar. 2016. Fenomena Kemiskinan Nelayan: Perspektif Teori Strukturasi. POLITIK 12(2):1857-1866.

Katmini, K. and A. Syakur. 2020. Pola Asuh Orang Tua Otoriter dengan Kemampuan Activities Of Daily Living (ADL) pada Anak Retardasi Mental Usia 6-12 Tahun di SLB Yayasan Putra Asih Kediri Tahun 2018. Briliant: Jurnal Riset dan Konseptual 5(1):163-171.

Lewis, O. 1959. Five Families: Mexican Case Studies in the Culture of Poverty. With a Foreword by Oliver La Farge. Basic Books New York.

Miles, M. B. and A. M. Huberman. 1994. Qualitative data analysis: An expanded sourcebook. sage.

Nurkaidah, N. 2016. Implementasi Kebijakan Pengentasan Kemiskinan Nelayan Tradisional di Kota Palopo. Universitas Negeri Makassar.

Nurwati, N. 2008. Kemiskinan: Model Pengukuran, Permasalahan dan Alternatif Kebijakan. Jurnal Kependudukan Padjadjaran 10(1):1.

Permensos (Peraturan Menteri Sosial tentang Pekerja Sosial Masyarakat). 2012. Pedoman Pendataan dan Pengelolaan data Penyandang masalah kesejahteraan sosial dan potensi dan sumber kesejahteraan sosial.

Poloma, M. M. 2010. Sosiologi Kontemporer, terj. Yasogama (Jakarta: Rajawali Pers, 2010).

Pratama, Y. C. 2014. Analisis faktor-faktor yang mempengaruhi kemiskinan di Indonesia. Esensi: Jurnal Bisnis dan Manajemen 4(2). 
Putera, S. T. 2011. Pengaruh PDRB, Pendidikan, dan Pengangguran terhadap Kemiskinan di Kabupaten/Kota Provinsi Jawa Tengah Tahun 2001-2010. Tesis, Fakultas Ekonomi Universitas Sebelas Maret Program Pascasarjana ....

Soekanto, S. 1999. Teori Sosiologi tentang pribadi dalam masyarakat. Ghalia Indonesia.

Statistik, B. P. 2018. Profil Kemiskinan di Indonesia Maret 2018. Jakarta (ID): Badan Pusat Statistik.

Sumarti, T. 2007. Kemiskinan petani dan strategi nafkah ganda rumahtangga pedesaan. Sodality: Jurnal Sosiologi Pedesaan 1(2).

Sutisna, W. P. 2013. Partisipasi Masyarakat dalam Implementasi Kebijakan Pembangunan di Daerah. Jurnal Desentralisasi 11(2):419-432.

Syakur, A. 2014. Analisis Dialek Lokal Sebagai Penanda Identitas Lokal Individu (Studiinterlanguage Mahasiswa Di Ilmu Administrasi Negara Stisospol "Waskita Dharma" Malang). JAMAK 1(1):14-18.

Syakur, A. 2018. Hubungan Kualitas Pelayanan Terhadap Kepuasan Mahasiswa dan Loyalitas Mahasiswa Ditinjau dari Model Pembelajaran di Akademi Farmasi Surabaya. Reformasi: Jurnal Ilmiah Ilmu Sosial dan Ilmu Politik 8(2):100-108.

Syakur, A. and R. Panuju. 2020. Peran Strategis Public Relation dalam Pengembangan Reputasi Pendidikan Tinggi: Studi Kasus Promosi di Akademi Farmasi Surabaya. Briliant: Jurnal Riset dan Konseptual 5(1):128-136.

Syakur, A., T. A. B. Susilo, W. Wike, and R. Ahmadi. 2020. Sustainability of Communication, Organizational Culture, Cooperation, Trust and Leadership Style for Lecturer Commitments in Higher Education. Budapest International Research and Critics Institute (BIRCI-Journal): Humanities and Social Sciences 3(2):1325-1335.

Syawie, M. 2011. Kemiskinan dan kesenjangan sosial. Sosio Informa 16(3).

Syuhada, M. I. 2019. Analisis Pengaruh Indeks Pembangunan Manusia (Ipm), Pdrb Dan Upah Minimum Terhadap Kemiskinan Studi Kasus Kabupaten/Kota Di Pulau Jawa. Fakultas ekonomi dan bisnis uin Jakarta.

Walidin, W. and S. Idris. 2015. Metodologi Penelitian Kualitatif \& Grounded Theory. FTK Ar-Raniry Press.

Wijayanto, R. D. and F. Arianti. 2010. Analisis pengaruh PDRB, pendidikan dan pengangguran terhadap kemiskinan di kabupaten/kota Jawa Tengah Tahun 2005-2008. Universitas Diponegoro 